\title{
Protestant Christian
}

National Cancer Institute

\section{Source}

National Cancer Institute. Protestant Christian. NCI Thesaurus. Code C103287.

A religious group encompassing numerous Christian denominations and a wide theological spectrum that have a common origin stemming from the Reformation which resulted in separation from the Catholic Church and its practices. 